Speakers bureau: AbbVie, Celgene, Janssen, Eli-Lilly, Novartis and UCB, Anna Moltó: None declared, Victoria Navarro-Compán: None declared, Karin Niedermann Schneider: None declared, Percival D. Sampaio-Barros: None declared, Gleb Slobodin: None declared, Filip van den Bosch Consultant for: AbbVie, BMS, Galapagos, Janssen, Lilly, Merck, Novartis, Pfizer and UCB, Speakers bureau: AbbVie, BMS, Janssen, Lilly, Merck, Novartis, Pfizer and UCB., Astrid van Tubergen: None declared, Salima van Weely: None declared, Michael Weisman: None declared, Dieter Wiek: None declared, Juergen Braun Shareholder of: AbbVie, BMS, Celgene, Chugai, Merck, Novartis, Pfizer, UCB, Grant/research support from: AbbVie, BMS, Celgene, Chugai, Merck, Novartis, Pfizer, UCB, Grant/research support from: Abbott, Bristol Myers Squibb, Celgene, Celltrion, Chugai, Johnson \& Johnson, MSD, Novartis, Pfizer, Roche, UCB Pharma, Grant/research support from: AbbVie, BMS, Celgene, Chugai, Merck, Novartis, Pfizer, UCB, Grant/research support from: Abbvie (Abbott), Amgen, Baxter, Biogen, BMS, Boehringer, Celgene, Celltrion, Centocor, Chugai, Hexal, Janssen, Lilly, Medac, MSD (ScheringPlough), Mylan, Mundipharma, Novartis, Pfizer (Wyeth, Hospira), Roche, Sanofi-Aventis and UCB, Consultant for: Abbvie (Abbott), Amgen, Baxter, Biogen, BMS, Boehringer, Celgene, Celltrion, Centocor, Chugai, Hexal, Janssen, Lilly, Medac, MSD (Schering-Plough), Mylan, Mundipharma, Novartis, Pfizer (Wyeth, Hospira), Roche, Sanofi-Aventis and UCB, Consultant for: AbbVie, BMS, Celgene, Chugai, Merck, Novartis, Pfizer, UCB, Consultant for: Abbott, Bristol Myers Squibb, Celgene, Celltrion, Chugai, Johnson \& Johnson, MSD, Novartis, Pfizer, Roche, UCB Pharma, Speakers bureau: AbbVie, BMS, Celgene, Chugai, Merck, Novartis, Pfizer, UCB, Speakers bureau: Abbvie (Abbott), Amgen, Baxter, Biogen, BMS, Boehringer, Celgene, Celltrion, Centocor, Chugai, Hexal, Janssen, Lilly, Medac, MSD (ScheringPlough), Mylan, Mundipharma, Novartis, Pfizer (Wyeth, Hospira), Roche, Sanofi-Aventis and UCB, Speakers bureau: AbbVie, BMS, Celgene, Chugai, Merck, Novartis, Pfizer, UCB

DOI: 10.1136/annrheumdis-2019-eular.4555

\section{THU0359 WHAT IS THE LEVEL OF AGREEMENT BETWEEN LOCAL AND CENTRAL READERS IN THE DETECTION OF ACTIVE AND STRUCTURAL LESIONS ON MRI TYPICAL OF AXIAL SPONDYLOARTHRITIS? DATA FROM THE ASAS CLASSIFICATION COHORT STUDY}

Walter P Maksymowych ${ }^{12}$, Xenofon Baraliakos ${ }^{3}$, Robert G Lambert, ${ }^{1}$ Ulrich Weber ${ }^{4}$, Joachim Sieper ${ }^{5}$, Stephanie Wichuk ${ }^{1}$, Denis Poddubnyy ${ }^{5}$ Mikkel Ǿstergaard ${ }^{6}$, Joel Paschke ${ }^{2}$, Susanne Juhl Pedersen ${ }^{1}$, Pedro Machado $^{7}$ ${ }^{1}$ University of Alberta, Edmonton, Canada; ${ }^{1} \mathrm{CaRE}$ ARTHRITIS, Edmonton, Canada; ${ }^{1}$ Rheumazentrum Ruhrgebiet, Herne, Germany; ${ }^{1}$ University of South Denmark, Odense, Denmark; ${ }^{1}$ Charité Universitätsmedizin, Berlin, Germany; ${ }^{1}$ Copenhagen Center for Arthritis Research, Copenhagen, Denmark; ${ }^{1}$ University College London, London, United Kingdom

Background: There has been no central reader evaluation of MRI scans from the ASAS Classification Cohort (ASAS-CC) ${ }^{1}$ to compare detection of lesions in the sacroiliac joints (SIJ) between central and ASAS-CC local site readers. Active MRI lesions typical of axSpA were reported in $61.6 \%$ and $2.2 \%$ of patients from this cohort diagnosed with axSpA and non-axSpA back pain, respectively ${ }^{1}$. Structural lesions were recorded but not reported in the literature.

Objectives: We aimed to compare detection of active and structural lesions on MRI images of the SIJ from the ASAS-CC between ASAS-CC local site readers and central readers from the ASAS-MRI group.

Methods: MRI images were available from 258 of the 495 cases who had MRI performed in the ASAS-CC and also had a local rheumatologist diagnosis. Seven central readers recorded MRI lesions in an eCRF that included wording of lesions defining active and structural lesions typical of axSpA that was exactly the same as in the original ASAS-CC eCRF permitting comparisons between central and local site readers. In addition, lesions that met the criteria for an ASAS positive $\mathrm{MRI}$ were recorded by central readers. Active and structural lesion frequencies were assessed descriptively according to majority agreement $(\geq 4 / 7)$ of central reader data and also any 2 central readers. Reliability of detection of MRI lesions was compared between central and local readers using the kappa coefficient.

Results: Significant differences in lesion frequencies were observed according to diagnostic category (Table 1 ). The frequency of active lesions reported by local readers $(61 \%)$ was greater than for central readers that agreed on the presence of an active lesion (49.7\%). Structural lesions were reported less frequently by local readers $(44.0 \%)$ compared to central readers that agreed on the presence of a structural lesion (54.9\%). Reliability of local readers for detection of active lesions was good but only fair for structural lesions (Table 2).

\begin{tabular}{|c|c|c|c|c|}
\hline \multirow[b]{2}{*}{ Reader } & \multirow{2}{*}{ MRI Lesion Type } & \multicolumn{2}{|c|}{$\begin{array}{c}\text { Local Rheumatologist } \\
\text { Diagnosis }\end{array}$} & \multirow{2}{*}{$P$ value } \\
\hline & & $\begin{array}{l}\text { AxSpA } \\
(\mathrm{n}=187)\end{array}$ & $\begin{array}{c}\text { Not AxSpA } \\
(n=71)\end{array}$ & \\
\hline Local & Active & $114(61.0 \%)$ & $3(4.2 \%)$ & $<0.0001$ \\
\hline Central ( $\geq 4$ in agreement) & Active & $83(44.4 \%)$ & $3(4.2 \%)$ & $<0.0001$ \\
\hline Central ( $\geq 4$ in agreement) & ASAS positive & $76(40.6 \%)$ & $2(2.8 \%)$ & $<0.0001$ \\
\hline Central ( $\geq 2$ in agreement) & Active & $93(49.7 \%)$ & $6(8.5 \%)$ & $<0.0001$ \\
\hline Central ( $\geq 2$ in agreement) & ASAS positive & $89(47.6 \%)$ & $5(7.0 \%)$ & $<0.0001$ \\
\hline Local & Structural & $72(44.0 \%)^{\sharp}$ & $3(5.2 \%)^{\#}$ & $<0.0001$ \\
\hline Central ( $\geq 4$ in agreement) & Structural & $51(31.5 \%)^{4}$ & $6(10.3 \%)^{\sharp}$ & $<0.0001$ \\
\hline Central ( $>2$ in agreement) & Structural & $89(54.9 \%)^{\#}$ & $10(17.2 \%)^{\#}$ & $<0.0001$ \\
\hline
\end{tabular}

\begin{tabular}{|c|c|c|c|c|c|}
\hline \multirow{2}{*}{\multicolumn{2}{|c|}{ Local Readers }} & \multicolumn{4}{|c|}{ Central Readers } \\
\hline & & \multicolumn{2}{|c|}{$\begin{array}{c}\text { Active lesion } \\
\text { (2 reader agreement) }\end{array}$} & \multicolumn{2}{|c|}{$\begin{array}{c}\text { Active Lesion } \\
\text { ( } \geq 4 \text { reader agreement) }\end{array}$} \\
\hline & & Yes & No & Yes & No \\
\hline \multirow{2}{*}{ Active lesion } & Yes & 85 & 32 & 78 & 39 \\
\hline & No & 14 & 127 & 8 & 133 \\
\hline \multicolumn{2}{|c|}{ Kappa (95\% CI) } & \multicolumn{2}{|c|}{$0.64(0.54-0.73)$} & \multicolumn{2}{|c|}{$0.62(0.53-0.72)$} \\
\hline & & \multicolumn{2}{|c|}{$\begin{array}{c}\text { Structural lesion } \\
\text { ( } 2 \text { reader agreement) }\end{array}$} & \multicolumn{2}{|c|}{$\begin{array}{c}\text { Structural Lesion } \\
\text { ( } \geq 4 \text { reader agreement) }\end{array}$} \\
\hline \multirow{2}{*}{ Structural lesion } & Yes & 58 & 17 & 43 & 32 \\
\hline & No & 41 & 104 & 27 & 118 \\
\hline \multicolumn{2}{|c|}{ Kappa (95\% CI) } & \multicolumn{2}{|c|}{$0.46(0.34$ to 0.57$)$} & \multicolumn{2}{|c|}{$0.39(0.27$ to 0.52$)$} \\
\hline
\end{tabular}

Conclusion: Local readers may have overestimated the presence of active lesions and underestimated the presence of structural lesions in the ASAS-CC. Their reliability for detection of structural lesions was limited which could reflect lack of awareness of structural lesions related to axSpA.

\section{REFERENCES}

[1] Rudwaleit et al. Ann Rheum Dis 2009;68: 777-83

Disclosure of Interests: Walter P Maksymowych Grant/research support from: AbbVie, Pfizer, Janssen, Novartis, Consultant for: AbbVie, Eli Lilly, Boehringer, Galapagos, Janssen, Novartis, Pfizer and UCB Pharma; Chief Medical Officer for Canadian Research and Education Arthritis, Xenofon Baraliakos Grant/research support from: AbbVie, Boehringer Ingelheim, Bristol-Myers Squibb, Celgene, Centocor, Chugai, Janssen, MSD, Novartis, Pfizer Inc, Roche and UCB, Grant/research support from: AbbVie, Pfizer Merck Sharp \& Dohme, UCB Pharma, Novartis, Consultant for: AbbVie, Bristol-Myers Squibb, Boehringer Ingelheim, Celgene, Chugai, Janssen Biologics, Novartis, Pfizer, UCB Pharma, Galapagos, Speakers bureau: AbbVie, Chugai, Janssen, Novartis, Pfizer, UCB Pharma, Robert G Lambert Consultant for: Bioclinica, Parexel, Abbvie, Ulrich Weber Consultant for: Abbvie, Joachim Sieper Consultant for: Abbvie, Böhringer Ingelheim, Janssen, Lilly, Merck, Mylan, Novartis, Pfizer, UCB., Speakers bureau: Abbvie, Böhringer Ingelheim, Janssen, Lilly, Merck, Mylan, Novartis, Pfizer UCB., Stephanie Wichuk: None declared, Denis Poddubnyy Grant/research support from: AbbVie, Merck Sharp \& Dohme, Novartis, Consultant for: AbbVie, Bristol-Myers Squibb, Janssen, Merck Sharp \& Dohme, Novartis, Pfizer, UCB Pharma, Speakers bureau: AbbVie, Bristol-Myers Squibb Janssen, Merck Sharp \& Dohme, Novartis, Pfizer, Roche, UCB Pharma, Mikkel Ǿstergaard Grant/research support from: Abbvie, Celgene, Centocor, Merck, Novartis, Consultant for: Abbvie, BMS, Boehringer-Ingelheim, Celgene, Eli Lilly, Hospira, Janssen, Merck, Novartis, Novo, Orion, Pfizer, Regeneron, Roche, and UCB, Speakers bureau: Abbvie, BMS, Boehringer-Ingelheim, Celgene, Eli Lilly, Hospira, Janssen, Merck, Novartis, Novo, Orion, Pfizer, Regeneron, Roche, and UCB, Joel Paschke: None declared, Susanne Juhl Pedersen: None declared, Pedro Machado Consultant for: Abbvie, BMS, Celgene, Janssen, MSD, Novartis, Pfizer, Roche and UCB, Speakers bureau: Abbvie, BMS, Celgene, Janssen, MSD, Novartis, Pfizer, Roche and UCB

DOI: 10.1136/annrheumdis-2019-eular.3158 